\title{
Plasmacytoma of the orbit involving lacrimal gland with secondary transformation into multiple myeloma: case report
}

\author{
Plasmocitoma da órbita envolvendo glândula lacrimal com transformação \\ secundária para mieloma múltiplo: relato de caso
}

\author{
Ivana Lopes Romero ${ }^{1}$ \\ Felipe Augusto Garcez de Campos ${ }^{2}$ \\ Renato Wendell Ferreira Damasceno ${ }^{3}$ \\ José Vital Filho ${ }^{4}$ \\ Simone Haber Duellberg' Von Faber Bison ${ }^{5}$
}

\begin{tabular}{l} 
ABSTRACT \\
\hline The authors present a rare case of plasmacytoma of the orbit involving \\
lacrimal gland with secondary transformation into multiple myeloma in \\
a 42-year-old woman. The lesion was surgically removed and analyzed. \\
Histopathological examination with immunostaining revealed it to be \\
positive for immunoglobulin G and Kappa chains, demonstrating mo- \\
noclonality. However, no abnormality was observed on serum elec- \\
trophoresis, skeletal survey and bone marrow aspiration. Therefore, \\
the tumor was diagnosed solitary plasmacytoma of bone. The patient \\
was treated with external beam radiotherapy and has remained disease \\
free for 5 years and 6 months until 2007, when she presented a patho- \\
logical fracture due to multiple myeloma. Extensive medical work-up to \\
rule out multiple myeloma or other malignant lymphoproliferative \\
conditions involving orbit or ocular adnexa is needed when the diagnosis \\
of solitary plasmacytoma of bone is suspected because treatment and \\
prognosis are very different.
\end{tabular}

Keywords: Plasmacytoma; Orbital neoplasms/radiotherapy; Lacrimal apparatus; Immunoglobulin kappa-chains; Neoplasm invasiveness; Multiple myeloma; Tomography, x-ray computed; Human; Female; Adult; Case reports [Publication type]
Trabalho realizado no Departamento de Oftalmologia da Irmandade da Santa Casa de Misericórdia de São Paulo.

${ }^{1}$ Estagiária do Setor de Oculoplástica do Departamento de Oftalmologia da Santa Casa de Misericórdia de São Paulo - São Paulo (SP) - Brasil.

2 Acadêmico do $4^{\circ}$ ano da Faculdade de Ciências Médicas da Santa Casa de Misericórdia de São Paulo - São Paulo (SP) - Brasil.

Estagiário do Setor de Oculoplástica do Departamento de Oftalmologia da Santa Casa de Misericórdia de São Paulo - São Paulo (SP) - Brasil.

${ }^{4}$ Chefe do Setor de Órbita do Departamento de Oftalmologia da Santa Casa de Misericórdia de São Paulo - São Paulo (SP) - Brasil.

${ }^{5}$ Professora Doutora e Chefe do Setor de Vias Lacrimais do Departamento de Oftalmologia da Santa Casa de Misericórdia de São Paulo - São Paulo (SP) - Brasil.

Endereço para correspondência: Rua Martinico Prado, 284 - Apto. 54 - São Paulo (SP) CEP 01224-010 E-mail: ilromero@gmail.com

Recebido para publicação em 17.04.2008

Aprovado em 08.12.2008

\section{INTRODUCTION}

Plasmacytoma is a solitary, localized tumor collection of clonal neoplastic plasma cells capable of producing a monoclonal immunoglobulin ${ }^{(1)}$. These tumors are classified as either solitary plasmacytomas of the bone (SPB) or extramedullary plasmacytomas (EMP) of soft tissue ${ }^{(2)}$. The commonest site for EMP is the upper respiratory tract, including the oropharynx, nasal cavities, sinuses and laryn $\mathrm{x}^{(3-5)}$, while the SPB frequently occurs in the axial skeleton.

Extramedullary plasmacytoma of the orbit, eyelid, ocular adnexa, as of the conjunctiva, occurs rarely ${ }^{(1,6)}$, and appears to have a different natural history than SPB, with a lower incidence of conversion to multiple myeloma. In contrast, SPB continues to convert to multiple myeloma even after 17 years. The continued conversion of SPB to myeloma suggests that these tumors are actually multiple myeloma in evolution ${ }^{(7)}$.

A rare case of plasmacytoma of the orbit involving lacrimal gland with secondary transformation into multiple myeloma of a 42 -year-old woman is presented. 


\section{CASE REPORT}

A 42-year-old woman presented proptosis in the right eye for 7 months evolving with progressive pain and vertical diplopia (Figure 1A) in April 2002.

On that occasion, visual acuity was preserved and no other changes were observed either in intraocular pressure or in indirect ophthalmoscopy. B-scan ultrasonography was performed showing acoustic brightness of solid mass in the right orbit. Standardized A-scan ultrasonography revealed low-amplitude internal reflectivity. Axial CT scan showed a large, globular mass occupying the lateral orbit with bone involvement (Figure 1B). A diagnostic biopsy was performed, displaying proliferation of plasmacytoid cells and the histopathology was consistent with plasmacytoma (Figure 2A). Immunohistochemical stains were positive for IgG Kappa light chains (Figure 2B), consistent with a monoclonal proliferation.

A systemic evaluation for multiple myeloma, including bone marrow biopsy, peripheral blood test, serum and urine immunoelectrophoresis, skeletal survey and CT scans of chest and abdomen, was negative. Therefore the diagnosis of plasmacytoma of the orbit was established. The orbital mass was treated with external beam radiotherapy (total dose of 5000 cGy).

In March 2003, the tumor regressed; however, after eleven months local recurrence involving lacrimal gland was observed. Detailed systemic work-up was negative for multiple myeloma, until October 2007, when the patient presented a lumbar fracture between L2-L3, infiltrative multifocal lesions in the spine and bone marrow biopsy with $7 \%$ of plasma cells.

On the basis of these findings, the diagnosis of multiple myeloma was established.

\section{DISCUSSION}

Malignant plasma cell tumors are divided according to site of origin. They can be multicentric, such as multiple myeloma, or localized, originating at bone (SPB) or from soft tissue (EMP). The latter is a malignant tumor that is thought to be separate neoplasm from multiple myeloma and plasmacytoma of bone, with a much better prognosis ${ }^{(3)}$.

Lesion size, total serum protein levels and the presence of a monoclonal spike on serum protein electrophoresis appear to correlate with risk of conversion to multiple myeloma. In addition, serum beta- 2 microglobulin may be a useful prognostic indicator ${ }^{(7)}$.

A few cases of solitary plasmacytoma of the orbit have been reported in the literature to date. Although males are affected more frequently than females in a 3 to 1 ratio and the age at presentation usually lies between the sixth and seventh decade of live ${ }^{(3,8)}$, our case is related to a 42-year-old woman.

The criteria for the diagnosis of SPB include negative lymph node assessment, skeletal survey, bone marrow biopsy and computed tomography ${ }^{(9-10)}$.

In addition, histopathological examination is essential to reach the diagnosis, and it is important, in particular, to demonstrate the production of monoclonal immunoglobulin by immunostaining. Our patient was diagnosed with SPB because monoclonality of IgG and Kappa light chains had been demonstrated by immunohistochemical examination and because clinical, hematological, biochemical and radiological investigations ruled out systemic diseases until 2007, when the patient presented a pathological fracture due to multiple myeloma.

The primary method of treatment of SPB is radiation therapy. The treatment of choice is external beam radiation with doses between 4000 to $6000 \mathrm{cGy}$ in 5 to 7 weeks $^{(3,11)}$.
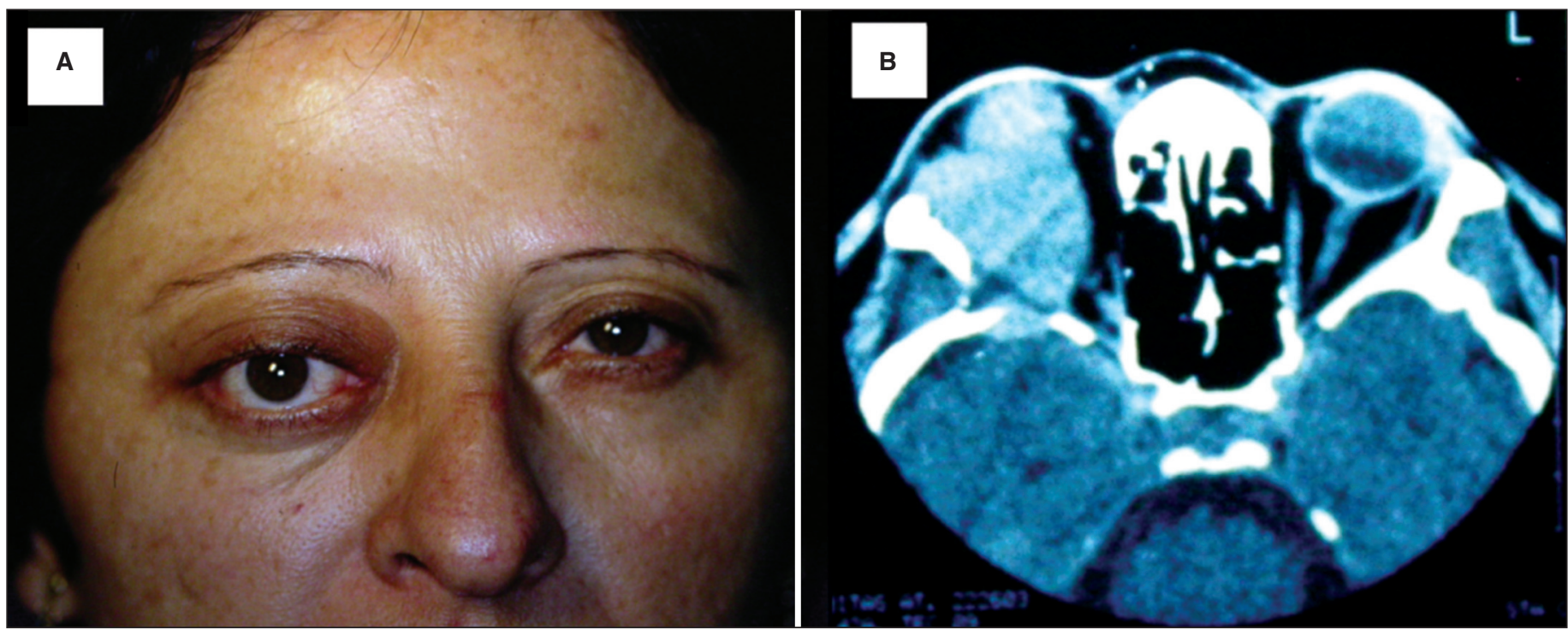

Figure 1 - A) Clinical photograph showing 42-year-old woman with proptosis in the right eye. B) Axial CT scan showed a large, globular mass occupying the lateral orbit with bone involvement. 

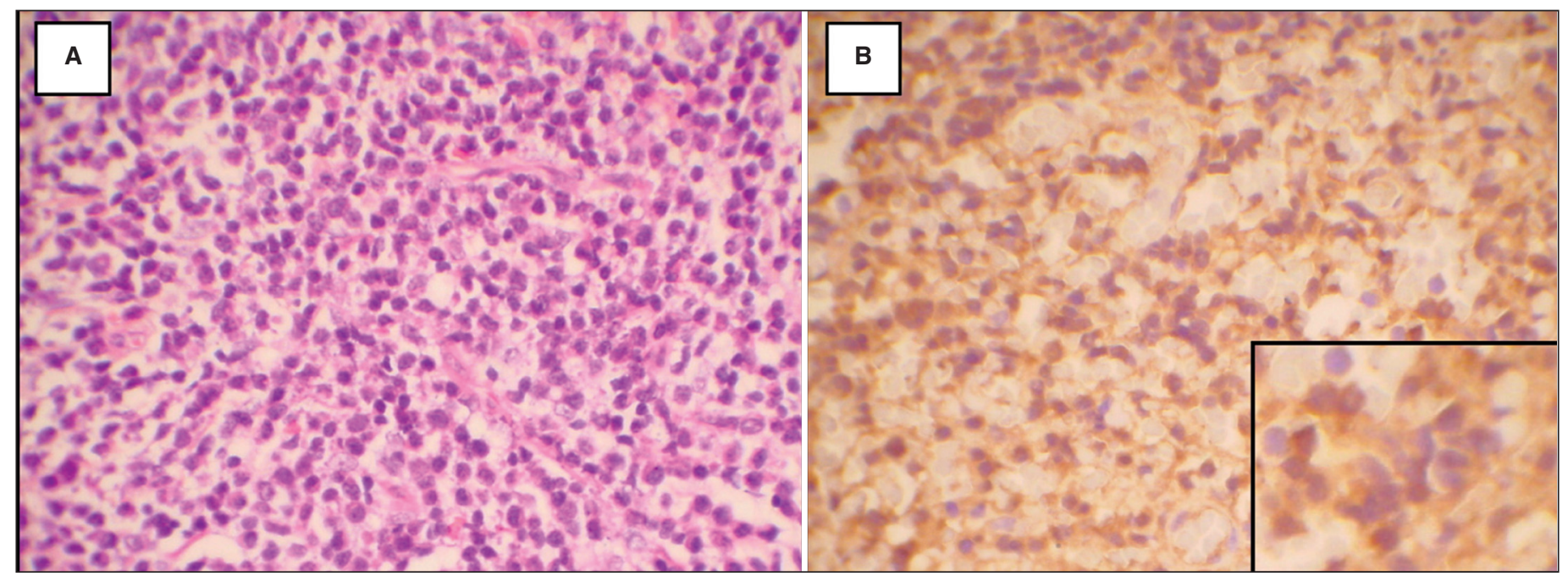

Figure 2 - A) Plasma cells diffusely infiltrate the orbit (hematoxilin and eosin). B) Immunohistochemical stain positive for Kappa light chain. Inset shows round eccentric nuclei.

In an attempt to prevent progression to multiple myeloma, adjuvant chemotherapy was administered in addition to local therapy for solitary plasmacytomas ${ }^{(7)}$. These authors showed chemotherapy delayed the time to conversion, although adjuvant chemotherapy did not affect the rate of conversion.

After treatment (radiotherapy), some patients with SPB have local recurrence, lymph node metastasis or remote metastasis, and some develop multiple myeloma, like our patient. Multiple myeloma is a plasma cell neoplasm characterized by plasma cell infiltration of bone marrow and by monoclonal immunoglobulin in the serum. Findings include bone pain, pathologic fractures, renal insufficiency, anemia, infection, and plasmacytomas. These patients should thus be followed carefully for a long period of time.

\section{RESUMO}

Os autores relatam um raro caso de plasmocitoma da órbita envolvendo glândula lacrimal com transformação secundária para mieloma múltiplo em uma paciente de 42 anos. A lesão foi removida cirurgicamente e o exame anatomopatológico, aliado à imuno-histoquímica, revelou positividade para imunoglobulina $\mathrm{G}$ e cadeias leve tipo Kappa. Após extensa avaliação sistêmica, nenhuma anormalidade foi observada, sendo feito o diagnóstico de plasmocitoma solitário ósseo. A paciente foi submetida à radioterapia, permanecendo livre da doença por 5 anos e 6 meses até 2007, quando apresentou uma fratura patológica devido à infiltração plasmocitária na coluna lombar, sendo feito diagnóstico de mieloma múltiplo. Uma vez que o plasmocitoma solitário ósseo pode ser a primeira manifesta- ção do mieloma múltiplo, esses pacientes necessitam de adequado diagnóstico e seguimento a longo prazo, pois o tratamento e prognóstico dessas duas condições é diferente.

Descritores: Plasmocitoma; Neoplasias orbitárias/radioterapia; Aparelho lacrimal; Cadeias kappa de imunoglobulina; Invasividade neoplásica; Mieloma múltiplo; Tomografia computadorizada por raios x; Humano; Feminino; Adulto; Relatos de casos [Tipo de publicação]

\section{REFERENCES}

1. Iida N, Saito K, Fukushima K. A case of extramedullary plasmacytoma arising from the lacrimal gland: a case report. Eur J Plast Surg. 2005;28(5):364-7.

2. Ahamed E, Samuel LM, Tighe JE. Extramedullary plasmacytoma of the eyelid. Br J Ophthalmol. 2003;87(2):244-5.

3. Uceda-Montañes A, Blanco G, Saornil MA, Gonzalez C, Sarasa JL, Cuevas J. Extramedullary plasmacytoma of the orbit. Acta Ophthalmol Scand. 2000;78(5): 601-3

4. Miller FR, Lavertu P, Wanamaker JR, Bonafede Je, Wood BG. Plasmacytomas of the head and neck. Otolaryngol Head Neck Surg. 1998;119(6):614-8.

5. Courtmans I, Pigeolet Y, Hedayat AH, Vilain J. Upper airways locations of plasmacytoma. Acta Otorhinolaryngol Belg. 2000;54(4):487-90.

6. Seddon JM, Corwin JM, Weiter JJ, Brisbane JU, Sutula FC. Solitary extramedullary plasmacytoma of the palpebral conjunctiva. Br J Ophthalmol. 1982; 66(7):450-4.

7. Holland J, Trenkner DA, Wasserman TH, Finenberg B. Plasmacytoma. Treatment results and conversion to myeloma. Cancer. 1992;69(6):1513-7.

8. Moragrega-Adame E, Velasco-Barona CF, Suarez-Tata M, Rodriguez-Reyes A Plasmocitoma orbitário com extension a glândula lagrimal: Reporte de um caso. Rev Mex Oftalmol. 2005;79(1):40-4.

9. Adkins JF, Shields JA, Shields CL, Eagle RC Jr, Flanagan JC, Campanella PC. Plasmacytoma of the eye and orbit. Int Ophthalmol. 1997;20(6):339-43.

10. De Smet MD, Rootman J. Orbital manifestations of plasmacytic lymphoproliferations. Ophthalmology. 1987;94(8):995-1003.

11. Mill WB, Griffith R. The role of radiation therapy in the management of plasma cell tumors. Cancer. 1980;45(4):647-52. 